MOTICES OF MFMOES.

I.-Preliminary Note on the Ordovichan Rocks of Shropshire. By Professor C. Lapworth, LL.D., F.G.S.

[A Paper read before the British Association, Birmingham, Section (C) Geology, September, 1886.]

TN this note the author gave a brief review of the history of discovery and opinion respecting the Lower Palæozoic rocks of Wales and the West of England, and pointed out that the results developed of late vears by British and foreign geologists made it. evident that Murchison's Silurian System, as defined in the later editions of "Siluria," was in reality composed of three distinct geological systems, and that of these three the only one which belonged to him by right of discovery and correct description was the so-called Upper. Silurian, which was therefore the only true Silurian System. The lowest known fossiliferous system (the Primordial Silurian of Barrande) was not discovered by Murchison, but by Sedgwick, who regarded it as the lower half of his own Cambrian System, and it ought, as a matter of justice and convenience, to retain that name only. The intermediate system (claimed as Lower Silurian by Murchison, and as Upper Cambrian by Sedgwick) belonged to neither, for its life-types are wholly distinct from those of the true Cambrian below and of the true Silurian above. This distinction must be recognized by a distinct title. The Silurian was named by Murchison after the ancient British tribe of the Silures, who inhabited South Wales, where its rocks attain their fullest development. The rocks of the disputed intermediate system, however, are most fully developed in North Wales-the land of the equally ancient tribe of the Ordovices. The author had proposed in 1879 that the middle system should be entitled the Ordovician System, after this old tribe, and this name is gradually coming into use among geologists.

During the last few years the sequence and fossils of the Ordovician strata of Shropshire have been studied in detail by the author, and their igneous rocks, both interbedded and intrusive, have been worked out by Mr. W. Watts. In this note a general summary of his own conclusions was communicated by the author, and illustrated by maps, sections and lists of characteristic fossils.

Ordovician strata occur in two distinct sub-areas in Shropshire, viz. in the district of Shelve and Corndon to the west of the Longmynd, and in the Caradoc district to the east of that range. In both districts these strata are overlain unconformably by the basement beds of the Silurian, which rest transgressively "pon every zone of the Ordovician in turn.

In the Shelve aud Corndon district the Ordovician rocks repose at once upon the highest known strata of the local Cambrian, and are arranged in the following ascending order:- 


\section{Shalve Series.}

(a) Stiper Group, consisting of the well-known Stiper Quartzites and their associated strata.

(b) Ladywell Group, composed of the dark shales and flagstones of Mytton, Juadywell and Hyssington, with Dichograptida and Ogygia Selwynii, etc.

(c) Stapeley Volcanic Group, andesitic lavas, ashes and interbedded shales.

\section{Meadowtown Series.}

(a) Weston Group of Grits, flagstones and dark shales.

(b) Middleton Group, composed of dark shales, with Didy. Murchisoni, and calcareous flagstones, with Ogygia Bucchi and Asaphus tyrannus.

(c) Rorrington Group, of intensely black shales, with Conograptus gracilis and Leptograptus.

\section{Chirburf Series.}

(a) Aldress Group, composed of the $S_{p y}$ Wood calcareous grit, and the Aldress Graptolitic shale.

(b) Marrington Group, including the Hagley volcanic ashes and shales, and the Whittery ashes and overlying shales.

The only Ordovician rocks occurring east of the Longmynd are those forming the local Caradoc Series of the author (the Caradoc formation of geologists). The basement beds of this series rest unconformably upon all the older rocks of the district-upon the socalled Uriconian, Longmyndian, Wrekin Quartzite, and Shineton Shales, and its component zones are each covered up unconformably in turn by the basement beds of the Silurian. 'This isolated Ordovician Series is composed of the following members:Caradoc Series.

(a) Hoar Edge Conglomerate, grits and limestone; (b) Harnage Shales; (c) Chutwall Sandstone; (d) Longville Flags; and (e) Omuy, or Trinucleus Shales.

The Shelve series answers generally to the strata commonly designated Arenig; the Meadowtown series includes the typical members of Murchison's Llandeilo; and the Chirbury and Caradoc series correspond broadly to Sedgwick's Bala formation of North Wales.

Some of the most characteristic fossils of each of the Ordovician sub-formations and zones were given, and it was shown how naturally the physical and palaentological sequence agrees with that of the corresponding Ordovician rocks of Britain and Europe. The peculiar physical conditions of the Shropshire area in Ordovician times, as indicated by the very different lithological characters of the strata upon the opposite sides of the Longmyud, was pointed out; and the evidences for the geological horizons and relationships of the volcanic rocks indicated in ontline. In conclusion, it was pointed out that the clearness and simplicity of the sequence, and 
the highly fossiliferous nature of its strata, render it tolerably certain that this Shropshire succession will form the general standard to which all other British Ordovician strata must ultimately be referred.

\section{II.-Transactions of the Cumbercand and Westmorland Asso- ciation. No. XI. 1885-86.}

TJHIS part contains notes on "The Mineral Springs near Keswick," 1 by J. Postlethwaite (pp. 142-145.) They comprise saline waters at Brandley Mine and Saltwell Park, and a chalybeate spring at Woodend Mine, near Threlkeld. Mr. 'T. V. Holmes contributes some remarks on "Purple-grey Carboniferous Rocks and the Whitehaven Sandstone" (pp. 146-148). He points out that purple-grey rocks, similar to the Whitehaven Sandstone, occur on almost every horizon throughout the Carboniferous series in Cumberland.

\section{正田巴W}

\section{I.-M. Dollo's Notes on the Dinosaurian Fauna of Bernissart.}

INHE remarkable preservation of a Fauna of Wealden reptiles at Bernissart has been utilized with admirable skill, so that the skeletons, though necessarily extracted in fragments, have been again reunited in the anatomical relations of the bones, in the Brussels Museum, under the able direction of M. de Pauw.

The animals thus displayed in a perfection which no other reptile fauna in Europe can surpass have been the subject of a series of valuable preliminary memoirs by M. Dollo, published during the last few years in the Bulletin du Musée Royal d'Histoire Naturelle de Belgique. The object in issuing these notes, in anticipation of the full description which is to follow, is professedly to gain from the criticism of scientific men suggestions which may aid in the perfection of the final monographs. I gladly avail myself of this opportunity for drawing attention to the excellent work which M. Dollo has thus far performed; and at the same time offer a few sugrgestions upon points where a difference of opinion seems to me legitimate.

The great interest of this work centres in the Dinosaurians, which were examined by M. Boulanger, and referred to the Iguanodon Mantelli, and a new species named by him Iyuanodon Bernissartensis, in days before M. Dollo commenced his labours.

The author begins by contrasting the differences between these two forms. Separating the characters of the animals, we are able to define the two types thus: Iguanodon Mantelli is a relatively small and slender animal, with a skeleton nearly twenty feet long. Its skull, $50 \mathrm{~cm}$. long, is relatively elongated, being moderately deep, and three times as long as wide. The anterior nares are long narrow vacuities, half as long as the lower jaw, and descending anteriorly for some distance over it. 'The orbit for the eye is rather longer than deep. The temporal vacuities, seen from above, are 